\title{
Highlights of the 2004 AAN activities for trainees
}

\author{
Karen C. Johnston, MD, MSc
}

\section{Free events for residents}

Scientific platform sessions

Poster sessions

Plenary sessions

Educational colloquium

Technical and association exhibits

Patient safety colloquium

Opening party (free ticket provided)

Awards luncheon (must reserve a free seat)

Resident/medical student/college student rush line-2 ticket/ course

Complimentary lunches in the exhibit hall
Selected sessions of special interest to trainees

Saturday, April 24-Saturday, May 1

Residents Lounge: 8:00 AM-6:30 PM

Saturday, April 24

Practice Issues for Residents and Fellows: 2:15-6 PM

Sunday, April 25

Patient Safety Colloquium: 9:0011:30 AM

Residents and Fellows Consortium: 1:30-2:30 PM

Monday, April 26

Education Colloquium: 9:0012:30 AM

American Board of Psychiatry and Neurology Symposium: 5:00-6:30 PM
Residents' Fellowship Panel, Poster Forum and Reception: 6:30-8:30 PM

Tuesday, April 27

Presidential Plenary Session: 9:00-11:30 AM

Futures in Clinical Research luncheon: 12:00-1:30 PM (preregistration required)

Wednesday, April 28

Contemporary Clinical Issues Plenary Session: 9:00-11:00 AM

Thursday, April 29

Frontiers in Clinical Neurosciences: 9:00-11:00 AM

Friday, April 30

Scientific Program Highlights Plenary Session: 5:15-6:15 PM

Full program information is available at http: / /am.aan.com 


\section{Neurology}

\section{Highlights of the 2004 AAN activities for trainees}

Karen C. Johnston

Neurology 2004;62;E18

DOI 10.1212/WNL.62.7.E18

\section{This information is current as of April 12, 2004}

\section{Updated Information \&}

Services

Permissions \& Licensing

Reprints including high resolution figures, can be found at: http://n.neurology.org/content/62/7/E18.full

Information about reproducing this article in parts (figures,tables) or in its entirety can be found online at:

http://www.neurology.org/about/about_the_journal\#permissions

Information about ordering reprints can be found online:

http://n.neurology.org/subscribers/advertise

Neurology ${ }^{\circledR}$ is the official journal of the American Academy of Neurology. Published continuously since 1951, it is now a weekly with 48 issues per year. Copyright . All rights reserved. Print ISSN: 0028-3878. Online ISSN: 1526-632X.

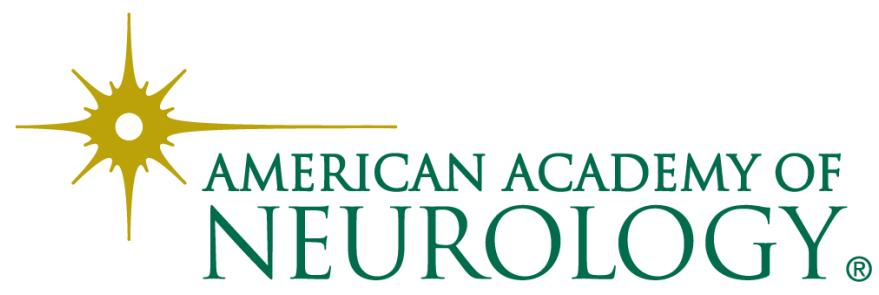

